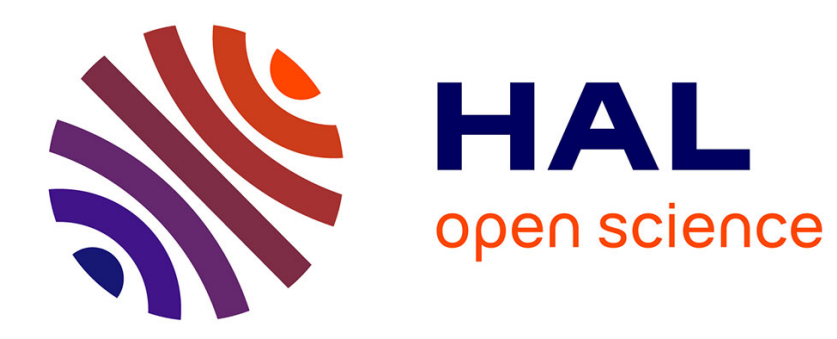

\title{
Technology standards, patents and antitrust
}

François Lévêque, Yann Ménière

\section{- To cite this version:}

François Lévêque, Yann Ménière. Technology standards, patents and antitrust. Competition and Regulation in Network Industries, 2008, 9 (1), pp.29-47. hal-00415570

\section{HAL Id: hal-00415570 \\ https://hal-mines-paristech.archives-ouvertes.fr/hal-00415570}

Submitted on 19 Nov 2009

HAL is a multi-disciplinary open access archive for the deposit and dissemination of scientific research documents, whether they are published or not. The documents may come from teaching and research institutions in France or abroad, or from public or private research centers.
L'archive ouverte pluridisciplinaire HAL, est destinée au dépôt et à la diffusion de documents scientifiques de niveau recherche, publiés ou non, émanant des établissements d'enseignement et de recherche français ou étrangers, des laboratoires publics ou privés. 


\title{
Technology standards, patents and antitrust
}

\author{
François Lévêque \\ Professor, Ecole des Mines, Paris \\ Visiting professor, UC Faculty of Law, Berkeley \\ Yann Ménière \\ Research fellow, Ecole des Mines, Paris
}

November 11, 2007 


\section{Summary}

From the perspective of antitrust authorities, the multiplication of patents embodied in technology standards is a source of concerns. Certainly it is necessary and efficient that patents owners derive a revenue from the use of the standard. Yet by their function ensuring compatibility between different products by promoting a common technology platform in a particular industry - standards generate potential for market power far beyond the legal protection conferred by patents. Patent holders may thus be tempted to leverage their position to make illegal profits. Such concerns arise in two different cases that have fuelled antitrust debates and economic research during the last decade. On the one hand, patent owners may be tempted to collude by coordinating their licensing policies. The difficulty here is that some coordination between them within a patent pool may actually be pro-competitive. After a brief introduction, we explain in the first part why, and on what conditions, patent pools should be accepted by antitrust authorities. On the other hand, patent owners may be tempted to manipulate the standard setting process by waiting for the wide adoption of the standard before charging excessive royalties to its users. We present this hold-up problem in the second part, and show how appropriate rules for standard setting processes can help mitigate it.

\section{Key words:}

\section{Introduction}

The number of patents worldwide has increased enormously in the past 20 years (Lévêque and Ménière, 2003). A similar inflation has taken place in technology standards, in which patents have become an inevitable component (Figure 1). The MPEG-2 video and audio compression standard, for example, incorporates 425 patents with 28 different owners. Similarly, the WCDMA mobile telephony standard is based on more than 6,000 patent applications owned by more than 30 firms. Besides the patent surge observed in Information and Communication technology, the growing number of patents reading on standards has various causes (Simcoe, 2005). Having one's patents incorporated in a standard has been increasingly perceived as an attractive source of revenue. Therefore manufacturers participating in standard setting have strengthened their propensity to disclose and claim standard-related patents, while new firms specialized in R\&D have started pushing their own proprietary technology in standard setting organizations.

Figure 1: Total IPR disclosures in: ANSI, ATIS, ETSI, IEEE, IETF, ITU, OMA, TIA (source: Simcoe, 2005). 


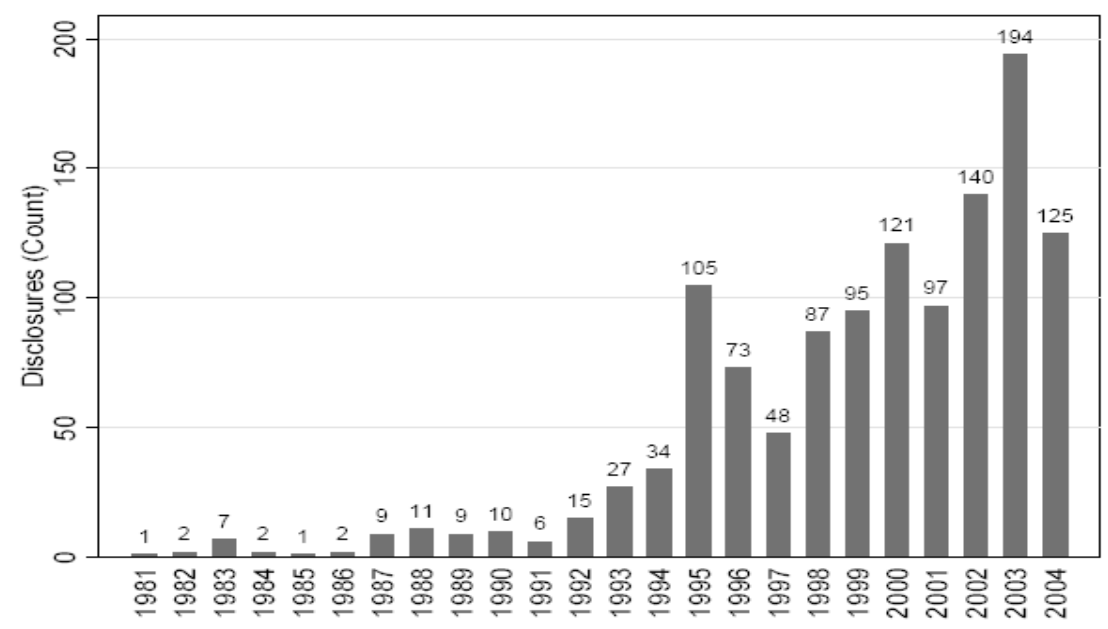

\section{I - Patent pools}

Patent pools aim at granting a single license for a package of patents belonging to different owners. Since the late 1990's, they have been used for licensing technology standards such as the Digital Versatil Disc, the MPEG video compression format or the $3 \mathrm{G}$ telecommunications norms. Such pools have been accepted by antitrust authorities although they clearly raise collusion concerns. Indeed, they can facilitate the diffusion of the standard to the benefit of both users and patent owners. We show in this part why it is so and how the risk of collusive patent pools can be prevented. We also highlight problems related to the formation of patent pools, that explain why they are systematically used to license standards.

\section{I.1 - PROCOMPETITIVE EFFECTS OF PATENT POOLS}

A large number of patents reading on a standard raises various issues when it comes to licensing those patents to producers of standard-compliant goods. Problems arise because many patents are owned by many patent owners, each of which is entitled to charge royalties to users of the standard. Decentralized licensing generates various inefficiencies that harm both licensors and licensees. By contrast, pooling patents and licensing them jointly can be welfare enhancing.

The first consequence of separate licensing is high transaction costs. Producers of standard-compliant goods must identify and assess the patents they need to license, contact all the relevant patent owners, and negotiate a separate license with each of them. The more numerous the patent owners are, the longer the timeframes, the broader the search and the higher the bargaining costs. Patent owners in turn incur parallel costs of monitoring and enforcing licensing contracts signed with the same licensees. From this perspective, organizing the joint licensing of all the patents is an intuitive move that mitigates these transaction costs. The patent pool dedicated to the MPEG-2 video compression standard is a good illustration of the efficiencies achieved by joint licensing. Owners of patents reading on MPEG-2 delegate to a jointly owned enterprise, MPEG LA, the task of licensing their patents as a single package. The pool was created in 1997 by 8 organizations holding some 100 patents representing $60 \%$ of the patents reading on the MPEG-2 standard. The pool has since expanded rapidly. In 2004 it was comprised of 650 patents owned by 25 organizations, accounting for more than $90 \%$ of the patents 
surrounding the standard. The MPEG-2 patent pool offers "one-stop shopping" to users of the standard. It thereby saves search and negotiation costs for would-be licensees. Notably, it also achieves economies of scale by handling the certification of patents, instead of leaving each patent holder to demonstrate that its own patents are valid and do read on the standard. These savings benefit both patent owners and standard users. Furthermore, by reducing the cost of licensing a standard, they facilitate its widespread adoption.

Besides mitigating transaction costs, the main rationale for creating patent pools is what economists refer to as multiple marginalization. This term originally designated the stacking of monopoly margins in vertical activity chains. Using the example of copper and zinc production monopolized by two firms, French economist Augustin Cournot (1838) demonstrated that the price of their alloy, brass, was higher than the price that would have been set by a single monopoly integrating the production of both metals. Whence the paradoxical result (often cited in merger control) that the merger of two vertical monopolies benefits consumers (as does, by extension, the non-horizontal merger of two firms with market power). It also benefits the firms because the joint profit from the new entity is higher than the sum of the profit of the two separate firms. This is possible because the products are complementary: by raising its margin on zinc, the non-integrated firm does not take into account the reduction in the quantity of copper sold by the other monopoly, and vice versa. This negative externality disappears when the firms merge. Applied to the standards covered by multiple complementary patents, the Cournot effect implies that the royalties claimed by each owner and the total amount of royalties will be too high compared with the economic optimum. As a consequence, the costs of using the standard are excessively high for licensees, thereby limiting diffusion of the technology. At the same time, patent owners earn less royalty revenue than they could have if they had coordinated their licensing policies.

Unlike with vertical chains, concentration between all patent owners may not be a realistic solution in the case of patents reading on technology standards. For instance, it is pure fantasy to envision a merger between Canon, France Telecom, Samsung, Fujitsu, General Electric, Bosch, Sony and the University of Columbia as a solution to the multiple marginalization problem in the case of the MPEG-2 standard. Creating a patent pool is a more realistic option, and with similar effects. Granting a package license with a single royalty for all patents prevents multiple marginalization. The royalty revenue can then be divided between patent owners on a previously agreed basis. As shown above, patent owners have a mutual interest in settling on a solution like this. However, as demonstrated below, there are various obstacles to the formation of patent pools, including clearance by the antitrust authority and agreeing on the royalty charged for the package (see inset below) and on the breakdown of revenue collected by the pool.

\section{Royalty negotiation between integrated manufacturers and pure patent holders}

The first standards in the information and telecommunications industries were developed by incumbent telephone monopolists and large hardware and software vendors. These companies were integrated, i.e., they both manufactured and sold the new technologies they had developed. They could cooperate easily on standard setting because they were a small number of similar companies. They competed only on downstream product markets. However, the standard setting environment has been changing (Simcoe, 2005). Alongside integrated manufacturers, small technology firms 
have become involved in the standard setting process. Unlike integrated manufacturers, these small firms are not involved in downstream markets. They derive all their profits from the sale of their inventions via licensing or buyouts. Generating revenue from their IPRs by having them incorporated into technology standards and licensed is therefore a key success factor in their business models.

The entry of pure patent holders has complicated the setting of cumulative royalties within patent pools. Integrated manufacturers and pure patent holders have vested interests in the matter that depend on their different organizations and business models. Pure patent owners derive their revenue solely from licensing. Hence their interest is to leverage the market power of the pool in order to set a high royalty. The interests of integrated manufacturers are different because of their presence on downstream product markets. On the one hand, they are licensors who derive more revenue from a high royalty. On the other hand, they are licensees who must pay royalties (e.g., the share of the package royalty that is distributed to the other patent owners) for their manufacturing activity. Because of this second effect, integrated patent owners are more reluctant to charge high cumulative royalties for the package of patents. Instead, they tend to push for lower royalties in patent pool negotiations (Kim, 2004). From a static standpoint, when the influence of integrated manufacturers in patent pools is strong, this tends to lower the total royalty and consequently the prices charged to consumers. Conversely, the stronger the influence of pure patent holders, the higher the royalty charged for the patent package, and the higher the prices charged to consumers.

\section{I.2 - ANTITRUST TREATMENT OF PATENT POOLS}

Besides their procompetitive effects, patent pools create various opportunities for their members to coordinate for anticompetitive purposes. These opportunities usually consist in pooling more patents than what is necessary to achieve procompetitive effects. This is the case when competitors pool substitute patents. For instance, in March 1998 the FTC challenged a pool created by Summit Technology, Inc and Visx, Inc, on the grounds that it was anticompetitive. The pool contained patents related to two different types of laser used for laser eye surgery, and removed price competition between the two products. As the FTC stated: "Instead of competing with each other, the firms placed their competing patents in a patent pool and share the proceeds each and every time a Summit or VISX laser is used." This observation holds a general lesson. Competition between substitute patents does not raise any multiple marginalization issue that needs to be fixed by joint price setting. On the contrary, in this case, separate price setting would ensure that price competition works to the benefit of consumers. The argument that cooperation reduces transaction costs is not relevant here, since customers only need to license one patent when patents are substitutes. To prevent anticompetitive effects, patent pools must therefore exclude substitute patents and include only complementary patents.

However, patent pools can also be anticompetitive even when they contain only complementary patents. They can be used to force licensees to buy a license on patents that they do not really need. This happens when some patents included in the package are complementary but not absolutely necessary for using the standard. Adding these kinds of patents to the pool can be a way to foreclose competition among substitute 
patents that could be used indifferently as complements to the essential patents, by picking one of them and putting it into the pool.

Preventing these forms of collusion requires severe screening of the patents that will be included in a pool. Antitrust authorities have therefore forged the concept of patent "essentiality" to determine which patents should be authorized in a pool. Essential patents are complementary patents that are necessary to the standard, have no substitute, and are legally valid. However, this definition is hard to put into practice. Knowing the exact scope and validity of a patent requires an in-depth assessment by experts. Moreover, the essentiality of patents may evolve over time, since standards are regularly updated as the technology is upgraded. From that perspective, the licensing rules applied by patent pools can be useful for screening essential and non-essential patents. Patent pools must comply with a set of licensing guidelines aiming at preventing discrimination and other abuses (see the box below). Among these rules, the requirement that members of a pool be allowed to license their essential patents separately from the pool works as an effective safeguard (Lerner \& Tirole, 2004; Lerner et al, 2005). The safeguard relies on the incentives for patent owners and licensees to circumvent the patent pool when the package license contains more than what users actually need. When that is the case, licensees would prefer to buy a smaller package at a slightly lower price. Supplying a reduced package outside the pool would also be profitable for the patent owners concerned. The threat of seeing the licensees escape can thus work as corrective mechanism for the patent pool; it prevents it from attempting to add non-essential patents to its package licence.

\section{Licensing rules in the MPEG-2 and DVD agreement}

In 1997 the U.S. Department of Justice issued the first of a series of business letters in response to a request by MPEG LA regarding the creation of a patent pool for the MPEG-2 standard. In 1998 and 1999 the Antitrust Division issued similar letters relating to the patent pool for the Digital Versatile Disc technology standard. Both pools have implemented the principles set forth in the letters, and are now considered as templates for the creation of other pools.

The principles applied by the MPEG-2 and DVD patent pools can be summarized as follows (Gilbert, 2004):

1. Limitation of the portfolio to technically essential patents which, by definition, are not competing with each other.

2. Portfolio patents are clearly identified and can be licensed individually as well as in a package.

3. Issue of worldwide non-exclusive licenses.

4. Licensee liability for royalty conditioned on actual use of the patents.

5. Freedom of licensees to develop and use alternative technologies.

6. When licensees have patents that are essential to comply with the technology, requirement that they grant back non-exclusive and non-discriminatory licenses on these patents.

The first principle requires that only essential patents be included in patent pools, and the second one provides for the independent licensing mechanism that upholds this principle. The next three principles (3-5) are meant to prevent the pool from imposing 
discriminatory or restrictive licensing clauses on its licensees. The last principle aims at preserving open access to the standard as the underlying technology evolves over time, by preventing patent owners outside the pool from trying to hijack the standard. The guidelines issued by the European Commission on technology transfer agreements contain similar principles.

\section{I.3 - PATENT POOL FORMATION CAN FAIL}

Like cartels, patent pools are unstable because members have incentives to deviate from the collective agreement. Deviations, however, take different forms in cartels and patent pools. Once a cartel is in place, its members may be tempted to increase their production or to reduce their price unilaterally, thereby free riding on the selfrestrictions imposed by the other members of the cartel. Things do not work this way in an authorized patent pool for, unlike illegal cartels, patent pooling agreements are enforced by legally binding contracts. Still, some patent owners may prefer not to participate in the patent pool so as to take advantage of the collective self-discipline accepted by those who did join the pool. This hold out problem arises basically because an essential patent owner can always charge a higher price if it manages to set its price after the others (U.S. DoJ \& FTC, 2007).

Why is it so? The incentives to free ride by holding out one's patents are connected to the multiple marginalization problem which patent pools are supposed to fix. Multiple marginalization occurs when patent owners set their individual royalties separately. Each charges a high royalty in order to maximize their individual profit. By doing so, they fail to take into account the fact that this high royalty will also reduce demand for licenses on other essential patents. Each patent holder is thus harmed by high royalties charged by the other patent owners. Hence all the patent owners are better off if they manage to jointly reduce their royalties. However, it is even more profitable for a single patent owner to let the others jointly reduce their royalties, while continuing to charge high royalties for its own patents. A game theory analysis (Aoki \& Nagaoka, 2004; Brenner, 2005) shows that, for this reason, no grand coalition of all patent owners forms when there is a large number of essential patents. Some patent owners prefer to stay out of the pool and derive the maximum benefit from the existence of a smaller pool. The WCDMA telecommunication standard is an extreme example of this problem. A $3 \mathrm{G}$ platform covering 5 standards (W-CDMA, EDGE, CDMA2000, TD-CDMA and DECT) was approved by U.S., European and Japanese antitrust authorities in 2002. In 2004 a joint licensing scheme was established with a cap of $5 \%$ for the collective royalty rate. Yet only 7 of the 73 firms claiming essential patents on W-CDMA committed to the collective license (Bekkers \& West, 2006). They include only one of ten largest essential patent owners. Qualcomm, which holds about one-third of the essential patents (Goodman \& Myers, 2005), did not join the pool, nor did Motorola, Ericsson or Nokia, the next largest essential patent holders.

Failing to agree on the way collective royalties will be split is an additional reason why the creation of patent pools can fail. On the one hand, essential patents may cover very different technologies, some of which are breakthroughs while others are mere improvements of prior art. They may have involved very different $R \& D$ costs for their owners. For these reasons patent owners may have their own expectations of the 
amount of royalty that should be due to their patents. On the other hand, each essential patent is necessary to use the standard, so that users would be willing to pay a high price even for a minor patent provided this grants them access to the standard. Reaching a consensus on how to split collective royalties can therefore be extremely difficult. In practice, patent pools often allocate royalties based on the number of patents owned by each member. This formula is applied by the MPEG-2 and 3G patent pools. It has the merit of simplicity and clarity, and it is acceptable when valuable patents are uniformly distributed among patent owners. It is, however, hard to accept for a member that owns a small number of highly valuable patents, and can in that case lead to a failure of the pool. The split of the DVD pool is a good illustration. The DVD pool was created in 1995 by 10 patent owners. However, Thomson eventually decided to quit the pool and license its patents separately. It was followed by Philips, Sony and Pioneer, which created a separate pool (hereafter, 3C). Both pools have since included new members and widely license their technology. The split was caused by a disagreement over how the royalty revenue was to be shared. The initial pool divided the royalties based on the number of patents, which was not acceptable for the members of the $3 \mathrm{C}$ pool. The $3 \mathrm{C}$ members hold an estimated $42 \%$ of the total patents, whereas the royalty share of the 3C pool is 56\% (Aoki \& Nagaoka, 2004). This suggests that the members of the 3C pool viewed their patents as more valuable than the average patent in the initial 10 -firm pool. 


\section{II - Standard development and hold-up}

Innovators have an interest in their patents being chosen by standards developers. The widespread adoption of their patents means that they will receive royalties from a large number of license holders. Competition between technology firms in standard-setting bodies can therefore be fierce as each firm seeks to prove the superiority of its innovation and thus influence the choice of standard in favor of its own patent portfolio. Alongside this above-board rivalry is the danger of anticompetitive behavior. For example, a firm can deliberately hide the fact that it owns an essential patent until the standard has been set and adopted. Given the amounts invested by users of the technology standard by that time, the patent owner can force them to pay much higher royalties.

This type of ambush was condemned in the Rambus case in the United States in August 2006. The Federal Trade Commission (FTC) found that by hiding its patents, the California-based firm was in violation of Section 2 of the Sherman Act. In December 2005, the European Commission approved a rewording of the rules of the European Telecommunications Standards Institute (ETSI) designed to safeguard against such attempts at concealment more effectively. In the related press release, the Commissioner for Competition, Nellie Kroes, said: "Standards are of increasing importance, particularly in hi-tech sectors of the economy. It is crucial that standard-setting bodies establish rules which ensure fair, transparent procedures, and early disclosure of relevant intellectual property"1. On both sides of the Atlantic, Qualcomm, a firm that owns many patents surrounding mobile telephony standards, is under fire from manufacturers of electronic components and terminals such as Broadcom, Nokia and Ericsson. The manufacturers accuse Qualcomm of not honoring its undertaking to license its patents on reasonable, non-discriminatory terms. How are these rules and behaviors analyzed from an economic viewpoint?

\section{Patent ambush: the Rambus case and ETSI's rules}

Rambus is a developer of electronic components, headquartered in California. The firm participated in the work to standardize random access memory (RAM) at JEDEC, the industry standard-setting body. Rambus took advantage of its involvement to word the claims of its patents in order to make sure that the new standard would infringe them, all the while leading the other members to believe that it had no patent covering the future standard. Rambus then sued the users of the standards for violating its IPR. The FTC held (in the matter of Rambus inc., Docket No. 9302, opinion of the Commission, August 2, 2006) that Rambus's acts of deception constituted exclusionary conduct, in violation of Section 2 of the Sherman Act. The FTC also accused Rambus of monopolizing the market in the technologies incorporated into the JEDEC standards, in violation of Section 5 of the FTC Act.

ETSI's rules are regularly reviewed by the European Commission. In the early 1990s ETSI adopted a policy on intellectual property that rendered patent ambush practically impossible. It imposed a kind of compulsory license on its members. Patents were automatically included in standards, unless their owners declared otherwise within six months. Furthermore, the owners of IPRs were required to notify the ETSI Director General of the maximum royalty they intended to charge. These default license

\footnotetext{
${ }^{1}$ Press Release, EC, IP/05/1565, 12 December 2005.
} 
obligations and ex ante licensing were withdrawn in 1994 after a complaint was filed by some members with the European Commission for infringement of antitrust law ${ }^{2}$.

Now, in terms of disclosure, ETSI members are required to use their reasonable endeavors to timely inform ETSI of essential patents, particularly when submitting a technical proposal for a standard or technical specifications. Members submitting a technical proposal must, on a bona fide basis, draw the attention of ETSI to any of their IPRs which might be essential if the proposal is adopted (see ETSI Guide on Intellectual Property Rights, version endorsed by General Assembly on November 22, 2006).

\section{II.1 - APPLYING THE ECONOMIC THEORY OF HOLD UP TO PATENTS}

Hold up theory is derived from economic research on the firm. Imagine a prime manufacturer that encourages one of its suppliers to buy a machine that can produce only parts that the prime manufacturer needs. The machine has a purchase value of, say, 1000 , and a resale value of only 10 (e.g., in the absence of the prime manufacturer's special request, the machine has only scrap value). Once it has invested in the machine, the supplier is captive and at the mercy of the buyer's opportunism. For example, the buyer can push the price at which it buys the parts down to the variable cost and thus prevent the seller from recouping its investment. The seller's only option is either to keep operating the machine for its customer or send it to the scrap heap. In both cases, it loses 990. O. Williamson (1985) attributes the vertical integration of firms to this risk of hold up. Opportunism is lower when transactions are conducted between two subsidiaries than between a buyer and a seller in the market.

Apart from the specifics of investment and opportunism, hold up can only occur when contracts are incomplete. Indeed, if the supplier is given a long-term contractual guarantee against a price cut by the buyer, it can invest in a dedicated machine without risk. Unfortunately, not every random variable can be foreseen in long-term contracts and some clauses can be interpreted differently by the two parties and by the judges. The renegotiation of contracts opens the gate to opportunistic behavior, and the risk of hold up is never zero; it can only be minimized.

This theoretical framework was applied to intellectual property by C. Shapiro (2001). Imagine that technology A has a value of 100 for its users and that the next-best technology in terms of quality has a value of 80 . If neither of the two technologies is patented, users will choose technology A and invest in it. For argument's sake, they need to spend 50 to make the specific complementary equipment to use the technology. Then imagine that, after users have made that investment, the owner of technology A leaps out of the woods and reveals that it holds a patent. The alternative facing users is either to buy the license requested by the owner of the submarine patent, or to switch to technology B. The latter option will cost them $50+20$, i.e., the cost of the complementary equipment specific to technology B, plus the difference in performance attributable to the use of this technology. The owner of technology A can therefore demand a maximum royalty of 70 .

Naturally, if users had anticipated the risk of hold up, they would not have invested in the equipment specific to technology A. Instead they would have opted for technology $B$, which offers inferior performance but is known to be unpatented. Hold up is

\footnotetext{
${ }^{2}$ Notice pursuant to Article 19(3) of Council Regulation No 17 concerning ETSI interim IPR policy, Official Journal, March 28, 1995, C 076.
} 
therefore not simply a matter of transfer at the expense of licensees; it also induces a loss of efficiency for society since users do not invest in the highest-performance technologies. It should also be noted that the amount of the royalty in a hold up situation is not a reward for innovation, which is the purpose of patent law. If the owner of technology A had declared itself from the outset, it could have asked a royalty of 20 at the most, i.e. the total benefit of its invention for users. In other words, hold up gives a patent holder greater ex post market power than the ex ante market power it gained from its patent. The difference is ascribable to the owner's opportunistic action and to the users' unrecoverable investment, not to the value of the innovation.

In the area of technology standards, the losses generated by hold up can be extremely high. The amounts firms waste on complementary equipment - and on the knowledge and experience required to adapt to a new standard - can be massive. The mobile telephony standards incorporated in networks and terminals give an idea of scale.

The costs of withdrawing from a technology standard are further increased by the loss of compatibility, which is the very reason for having a standard. A firm that abandons the standard unilaterally and uses an alternative technology loses the possibility of aligning its product on others, which reduces that product's attractiveness to consumers. An illustration from mobile telephony would be a situation where the customers of each operator could only call and be called by subscribers to the same operator. The benefit of compatibility can only be preserved if users opt simultaneously for the other technology. In practice, this implies starting a new standardization process, which is inevitably long and costly. In the case of technology standards, patent hold up can create a considerable additional market power gain.

\section{II.2 - RULES ON DISCLOSURE OF PATENTS}

The requirement on firms that are competing to have their technology chosen for a standard to disclose their patents is an obvious necessary rule to avoid hold up. However, enforcing this requirement is not easy. Firms - or at least their representatives in the working groups of standards developers - do not have accurate knowledge of their patent portfolios. A portfolio often contains thousands of patents, each of which consists of at least ten claims whose interpretation can be complex. The search cost involved in identifying the patents that cover the technologies in the standard is not negligible. Furthermore, the content of the standard being developed evolves in line with the discussions. A patent search can turn out to be pointless if the patented technology is not chosen. In principle, disclosure must also include pending applications for patents. But the claims that will be accepted are not always known in advance; it is therefore difficult to know whether a patent will be licensed for the use of the standard. In practice, standard-setting bodies ask their members to disclose their patents without requiring them to conduct a search. ETSI is a good example of this. It requires its members to act in good faith when disclosing their patents (see Inset: Patent ambush: the Rambus case and ETSI's rules) but expressly indicates in Article 4.2 of its IPR Policy that this rule does "not imply any obligation on members to conduct IPR searches". Moreover, ETSI does not provide for any precise, specific penalty for firms that do not comply with the disclosure rules. As for any other violation of its IPR Policy, it only provides for the General Assembly to take action against infringers. A simple sanction would be to force members that fail to disclose their patents to license 
their technology with no royalty. This kind of rule is applied by VITA (see Inset: VITA, an avant-garde policy against patent hold up?).

\section{VITA, an avant-garde policy against patent hold up?}

VITA is an incorporated non-profit organization that promotes architectures based on the VMEbus computer technology. Through its standard-setting committee, it is one of the smallest organizations in the powerful American National Standards Institute. It was recently granted approval from the U.S. Department of Justice for its new patent licensing policy ${ }^{3}$. The policy is innovative in several ways.

First, the participants in VITA's standard-setting work are required to state the maximum royalty they will charge for their patents. Naturally, this ex ante commitment is underpinned by an obligation to disclose essential patents that could be incorporated in technology standards under consideration. Participants have precise timeframes for disclosing their patents and must have conducted a reasonable search in good faith to identify them. Unsurprisingly, it is expressly stated that no negotiation about the terms of the licenses can take place during the working group meetings. This is to prevent the participants from using the forum offered by the standards-setting committee for anticompetitive purposes.

Second, VITA members must declare in advance any restrictive terms in their licenses. In particular, these include any obligations on licensees in terms of reciprocal licensing. With respect to the undertaking on royalties, the license terms are irrevocable. More accurately, the patent owner can only subsequently lower its royalties or loosen its conditions.

Third, VITA's policy provides for a system of penalties. In the event of non-disclosure of essential patents involved in standards or failure to comply with the undertaking on the license terms, the participants are obliged to license their technology for no royalty and with no restrictions on use. These penalties are handed down by the Executive Director of VITA and then by the appeals board on the basis of a recommendation by an arbitration tribunal.

Most standards developers ask their members to undertake to apply RAND conditions to their intellectual property licenses (an F for Fair is often prefixed to the acronym, especially in Europe). What is the significance of this undertaking? How can "reasonable and non-discriminatory licensing" be interpreted from an economic standpoint?

There are two opposing legal views of the purpose of RAND licensing. D. Géradin (2006) considers that the rationale of RAND terms is to prevent refusals to license that would block the use of a standard. By signing a RAND undertaking, the owner of the essential patent agrees to enter into good faith negotiation with any license applicant. G. Ohana et alii (2003) and M. Lemley (2007) contend that RAND terms are a solution to the problem of hold up. Patent owners thus agree not to put a gun to the heads of the standard users to extort some of the value of their sunk investments.

\section{II.3 - WHAT IS A REASONABLE ROYALTY?}

\footnotetext{
${ }^{3}$ DoJ Business Review Letter, October 2006, available on http://www.usdoj.gov/atr/public/busreview/219380.htm
} 
Economists share the second view. They propose (see, in particular, Swanson and Baumol, 2005, C . Shapiro, 2006 and J. Farrell et alii, 2007) a precise definition of a reasonable royalty, which can be summarized by the following equation:

$\mathrm{R}=\mathrm{c}+\left(\mathrm{V}_{1}-\mathrm{V}_{2}\right) \mathrm{p}$

The variable $\mathrm{c}$ is the incremental cost of licensing. It represents the licensing costs incurred by the patent owner for negotiation, royalty collection and any related services (e.g., training for the licensee). $\left(\mathrm{V}_{1}-\mathrm{V}_{2}\right)$ measures the gain for users of choosing the best technology over the second-best. The variable $\mathrm{p}$ represents the probability that the patent is valid.

The formula can be applied first to show that "reasonable" does not mean "free". If the patents cover two technologies that are perfect substitutes, then $\mathrm{V}_{1}=\mathrm{V}_{2}$ and therefore $\mathrm{R}=\mathrm{c}$. If the users of the standard offer less $\mathrm{c}$ to the owners, the latter will choose not license their technologies because they would lose money.

For the sake of the example, now imagine that $\mathrm{c}$ is negligible and that the patent on the best technology is valid. The maximum amount of a reasonable royalty is therefore equal to the difference in the value of the technologies for users, $V_{1}-V_{2}$. Users will only be willing to adopt the best technology if the amount of the royalty does not exceed the gain it offers over the alternative, second-best technology. This royalty amount enables the owner of the superior technology to reap the entire gain of its innovation for users. This is the role of patents as an incentive to innovate: the temporary monopoly enables the owner to extract most of the wealth generated by its invention for society. In other words, a reasonable royalty amounts precisely to the market power authorized by the patent. This point is essential because it means that RAND licensing does not block or erode the exercise of IPRs. Factoring in the probability of patent validity confirms that conclusion. Standards can contain uncertain patents, but this risk should be taken into account in the royalty amount. The economically optimal price of a license falls when the patent might infringe another patent, or when it does not fully meet the criteria of being new, non-obvious and useful. This rule applies to patents incorporated into standards as much as to any other patents.

A reasonable royalty can be conceptualized as the price determined by an auction mechanism before the standard is set. In other words, it is a competition between all the technologies that can be selected in which each patent owner states the royalty it intends to ask if its technology is chosen. This equivalence prompted Swanson and Baumol (2005) to recommend that standards developers introduce this mechanism, called ex ante licensing. However, various obstacles make this solution to hold up impracticable. First, an auction mechanism becomes highly complex when the technological elements of the standard are interdependent, i.e., when the value of a technology in terms of performing a function of the standard depends on the technology chosen to perform another function of the standard. Second, especially when the number of participants is limited, auctions can be manipulated and lead to collusion prices. Lastly, this mechanism involves assessing a large number of patents and technologies that will not be used in the end. While the standard is in the development phase, its technical content is still fluctuating and uncertain. Organizing a price competition between potential components of the standard initially considered but subsequently abandoned generates unnecessary costs. 
In light of the above, an ex ante licensing model in which patent owners agree in advance to ask a reasonable royalty but only set its exact amount once the standard has been chosen seems less costly. However, it is not as effective at containing the risk of hold up. When a patent owner undertakes to license on RAND terms, the amount it has in mind might be quite different from the amount expected by users. In the absence of a precise figure, these diverging expectations remain hidden. Consequently, if users underestimate the value of a license, they might then wrongly claim hold up; conversely, a patent owner can conceal a hold up attempt behind a supposedly bona fide overvaluation. The imprecision of the R in RAND leaves the gate open to disputes that are difficult to judge. It is easier for a judge to rule on a licensing contract that specifies a price than on one that refers only to a "reasonable" royalty.

The antitrust authorities are sometimes called to decide whether a royalty is "reasonable". For example, when applying remedies to an abuse of a dominant position by refusing to license, they must either set an access price or approve the access price proposed by the parties. The reasonableness of royalties is still a point in dispute between the European Commission and Microsoft (see Press Release, EC, IP/07/269, March 1, 2007). Another example is antitrust complaints for failure to license on RAND terms. In the USA, Broadcom, a manufacturer of chips for mobile telephones, filed a complaint against Qualcomm, which makes the same type of component and also owns upstream patents surrounding the second-generation (CDMA) and third-generation (WCDMA) technology standards. Broadcom accuses Qualcomm of refusing to license these patents to it on FRAND terms. Broadcom was non-suited in September $2006{ }^{4}$. In Europe, Broadcom and five other firms, including Nokia, filed a complaint with the European Commission against Qualcomm for abuse of a dominant position, particularly by refusing to license its essential patents on FRAND terms ${ }^{5}$.

\section{NON-DISCRIMINATORY LICENSING}

The economic interpretation of reasonable royalties, based on the idea of ex ante competition outlined above, is acceptable to lawyers because it closes a loophole. Meanwhile, the economic interpretation of non-discriminatory royalties is developing in a field better charted by the law. Here economists have to align themselves on the legal interpretation of non-discrimination.

Non-discrimination in access to an essential input is a cornerstone of sector regulation law. In the case of a rail network, a telephone local loop or an airport hub, a nondiscriminatory access price is one that does not distort competition between users of the monopoly infrastructure, in particular between new entrants and the vertically integrated incumbent operator. Users are allowed to win advantages over their rivals through merit, not because they have had easier access to the network. Nondiscriminatory licensing is thus linked to the concept of a level-playing field.

The economic interpretation of access price discrimination is related to the idea of setting different prices according to the characteristics of demand. For example, a wellknown economic rule, the Ramsey rule, involves setting a higher price for users of the

\footnotetext{
${ }^{4}$ See ruling on: http://www.qualcomm.com/press/PDF/broadcom_opinion.pdf and the case is now pending appeal.

5 S e $\quad$ B r o a d c o m s $\quad$ press $\quad$ rele a s e s http://www.broadcom.com/press/release.php?id=774809 and Qualcomm's http://www.qualcomm.com/press/releases/2005/051028_eucom_response.html.
} 
infrastructure with the lowest price elasticity of demand. From an economic viewpoint, discrimination is not always counter to the interest of consumers and society. It can be an efficient way to recoup investment costs and encourage agents to invest. In the case of intellectual property, royalty discrimination, as opposed to a single fee, gives the inventor a greater share of the value of its invention for users. This prospect enables a larger number of inventions to be produced (Lévêque and Ménière, 2003). From an economic viewpoint, the obligation of non-discrimination can harm consumers. But that is not how the ND in RAND should be understood.

Rather, economists need to adopt the legal definition of non-discrimination: the licensing of patents reading on the standard must not distort competition between users. To use a more up to date expression, the IPR owners agree, if they are or become vertically integrated, not to foreclose the markets in goods using the standard through their licensing contracts.

This interpretation is similar to that developed by Swanson and Baumol (2005), who see the possibility of foreclosure by a vertically integrated firm as the main justification for the ban on discrimination in the RAND undertaking. They also propose making this definition operational by applying a specific pricing principle, the Efficient Component Pricing Rule (ECPR).

\section{The Efficient Component Pricing Rule}

The ECPR originated with the deregulation of network industries. It links the access price to monopoly infrastructure (e.g., railway line, local loop) to the end price of the services that use it (e.g., train tickets, telephone calls). The ECPR thus sets an access price that is equal to the operator's end price minus the incremental cost of all the inputs other than the access consumed by the operator. This amounts to allowing the integrated operator to price access at the operating cost plus the opportunity cost, i.e. the financial loss from losing customers to the new entrant. It is therefore neutral on the profit of the owner of the infrastructure to provide access and not to supply the downstream services or not to offer access and to remain the exclusive supplier of those services. New entrants must be at least as efficient as the incumbent operator. At that price, only firms whose costs are lower than those of the downstream subsidiary of the incumbent operator can make a profit. This pricing rule is often criticized for not reducing the monopoly rent of the incumbent operator. Its defenders respond that the ECPR seeks to set a price that is neither too low, which would encourage the entry of inefficient firms, nor too high, which would lead to unnecessary duplication of the infrastructure. The rule ensures that the downstream market is competitive. Its purpose is not to end undue market power.

However, because this pricing rule is neutral on the profit of the owner of the input, it does not solve the problem of hold up. The owner of an integrated patent that sets a royalty above $\mathrm{c}+(\mathrm{V} 1-\mathrm{V} 2) \mathrm{p}$ will pass the ECPR test as long as its end price is equal to the amount of the royalty plus the incremental cost of the other inputs needed to make the downstream product. Conversely, if the owner of the integrated patent subsidizes its downstream activity by charging a lower royalty to its downstream subsidiary than to its more efficient competitors, it will fail the ECPR. The application of the ECPR aims to avoid the monopoly on the license market being leveraged to downstream markets. Swanson and Baumol [2005 p.17] stress this exclusive purpose: "The fact that 
ECPR alone does not eliminate monopoly profit or monopoly power is no more to its discredit than the fact that it does not help to cure cancer or baldness or solve any other problems it was not designed to remedy.".

Still, using the ECPR to identify an exclusionary practice by the owner of the integrated patent is a rather peculiar way to demonstrate violation of Article 82 or Section 2 of the Sherman Act, namely eliminating an equally efficient competitor. Apart from being difficult to apply, the ECPR test overlooks some behaviors that harm competition and consumers (F. Lévêque F., 2007). In practice, it has never been used by the US courts nor, apparently, by the European antitrust authorities. There does not seem to be any valid reason for choosing this test over another (e.g., the no economic sense test or the consumer harm test) to establish whether a patent owner has fulfilled its nondiscriminatory licensing undertaking. The only specific feature of leveraging a dominant position protected by an IPR is that the incentives are stronger than for other monopolies. That is because a patent offers only a temporary monopoly. Its validity is limited in time by the legal limit of protection. Often patents do not even last that long because competitors can conduct research just outside the scope of the patent and develop a substitute technology. This is even more likely when the patent and its claims are narrow.

Observe finally that the R and the ND in RAND are highly complementary. When properly enforced, the reasonable royalty requirement eliminates the market power linked to hold up, while leaving intact the market power linked to the temporary monopoly of intellectual property. Meanwhile, the non-discrimination obligation prevents that market power from being leveraged to downstream markets.

In conclusion, the increasing number of patents in technology standards is raising new problems. The focus should be shifted away from collusive practices. On the contrary, to remedy the problem of multiple marginalization, the coordination of patent owners should even be encouraged. Standards developers must endeavor to contain attempts at hold up and exclusionary practices on downstream markets. The obligation of RAND licensing they require of their members contributes to this. The antitrust authorities must also intervene when patent owners breach that undertaking not to extract a monopoly rent beyond that derived from the intellectual property and not to use it to obtain a monopoly on a downstream market. 


\section{References}

Aoki, R., Nagaoka, S. (2004) "Coalition Formation for a Consortium Standard through a Standard Body and a Patent Pool" Working paper, Institute of Innovation Research, Hitotsubashi University.

Bekkers, R., West, J. (2006) "The Effect of Strategic Patenting on Cumulative Innovation in UMTS Standardization" DIME Working Paper.

Brenner, S. (2006) “Optimal Formation Rules for Patent Pools”, mimeo.

Cournot A., (1838) Recherches sur les principes mathématiques de la théorie des richesses, Calmann-Lévy, 1974.

Geradin D. (2006) "Standardization and Technological Innovation: Some Reflexions on Ex ante Licensing, FRAND, and the Proper Means to Reward Innovators" TILEC Discussion Paper DP 2006-017.

Farrell J. (2007), J. Hayes, C. Shapiro, T. Sullivan "Standard Setting, Patents, and Holdup" http://faculty.haas.berkeley.edu/shapiro/standards2007.pdf.

Gilbert, R. (2004) "Antitrust for Patent Pools: A Century of Policy Evolution," Stanford Technology Law Review, available at http://stlr.stanford.edu/STLR/Core_Page/.

Goodman, D., Myers, R. (2005) “3G Cellular Standards and Patents” CIEEE.

Lemley M. A. (2007) "Ten Things to do about Patents holdup of standards (and one Not to)” Boston College Law Review, Vol XLVIII, n 1 pp 149-168.

Lemley M. A. and C. Shapiro (2006) "Patent Holdup and Royalty Stacking" Stanford Law and Economics Olin Working Paper, No. 324.

Lerner J. and Tirole J. (2004) "Efficient Patent Pools" American Economic Review, 94:3, 691-711.

Lerner, J., Strojwas, M, Tirole, J. (2005) "The Design of Patent Pools: the Determinants of Licensing Rules" IDEI Working Paper n. 187.

Lévêque F., Quel test de preuve pour l'article 82, Revue Lamy de la Concurrence, $2007 / 11, n^{\circ} 804$

Lévêque, F. et Ménière Y., Economie de la Propriété intellectuelle, Coll. Repères, Edition La Découverte, 2003.

Majoras D. P. (2005) "Recognizing the Procompetitive Potential of Royalty Discussion in Standard Setting", Standardization and the Law, Conférence organisée par l'Université de Stanford, 23 septembre. 
Miller J. (2006) "Standard Setting, Patents and Access Lock-In: RAND Licensing and the Theory of the Firm" forthcoming in Indiana Law Review 40.

Pate R. H. (2005) "Competition and Intellectual Property in the US: Licensing Freedom and the Limits of Antitrust" EU Competition Workshop, Florence, June 3.

Ohana G., Hansen M. and Shah O. (2003) "Disclosure and Negotiation of Licensing Terms Prior to Adoption of Industry Standards: Preventing Another Patent Ambush", European Competition Law Review, 24(2), 622-656.

Shapiro C (2001) "Navigating the Patent Thicket: Cross Licences, Patents Pools, and Standard Setting", in A. Jaffe, J. Lerner et S. Stern (sous la direction de), Innovation Policy and the Economy, Vol 1, MIT Press.

Shapiro C (2006) "Injunctions, holdup and Patent Royalties" Working papers, Competition Policy Center UC Berkeley, August.

Simcoe, T. (2005) "Explaining the Increase in Intellectual Property Disclosure”, mimeo

Swanson D. and W. Baumol (2005) "Reasonable and Nondiscriminatory (RAND) Royalties, Standards Selection, and Control of Market Power" Antitrust Law Journal 73:1.

U.S. Department of Justice \& Federal Trade Commission, Antitrust Enforcement and Intellectual Property Rights: Promoting Innovation and Competition, April 2007. Available at http://www.ftc.gov/reports/index.shtm.

Williamson O. (1985), “The Economics Institutions of Capitalism: Firms, Markets, Relational Contracting”, 52-56, 1985. 